It is possible that the continued study of these phenomenons in the light of the hypothesis of an agent-target interaction and a limitation of disposal by katabolic pathways may throw some light on the mechanisms whereby the recorded growth depressions are brought about. Further work is needed to define the specificity of the established interactions-the identity of alternative agents and targets-and to associate awareness of the involvement of individual amino acids in metabolic pathways.with patterns of plasma amino acid levels and nitrogenous excretory compounds.

\title{
REFERENCES
}

Florentino, R. F. \& Pearson, W. N. (1962). F. Nutr. 78, 101.

Harper, A. E. (1958). Ann. N.Y. Acad. Sci. 69, 1025.

Harper, A. E. (1964). In Mammalian Protein Metabolism. Vol. 2, p. 87. [H. N. Munro and J. B. Allison, editors]. New York: Academic Press Inc.

Lewis, D. \& Smith, G. H. (1963). Proc. int. Congr. Nutr. vi. Edinburgh, p. 479.

Lewis, D., Smith, G. H. \& Payne, C. G. (1963). Brit. F. Nutr. 17, 415.

Rosenberg, H. R., Culik, R. \& Eckert, R. E. (1959). F. Nutr. 69, 212.

Salmon, W. D. (1958). Amer. F. clin. Nutr. 6, 487.

Smith, G. H. \& Lewis, D. (1964). Proc. Nutr. Soc. 23, xxviii.

Smith, G. H. \& Lewis, D. (I g66). Brit. F. Nutr. (In the Press.)

Struck, J. \& Sizer, I. W. (1960). Arch. Biochem. Biophys. 9o, 22.

Winje, M. E., Harper, A. E., Benton, D. A., Boldt, R. E. \& Elvehjem, C. A. (1954). F. Nutr. 54, r 55

\section{A comparative study of performance on high-protein diets of unbalanced amino acid composition}

\section{By K. J. Carpenter and H. J. H. de Muelenaere*, School of Agriculture, University of Cambridge}

It is convenient to compare food proteins by a standardized procedure using one fixed level of protein in each test diet. The level is chosen to be sufficiently low so that the response, even for a good protein, is suboptimal. Such experiments can answer some questions, but not "how much of one particular protein food must be used in order to obtain the desired rate of growth (or performance) in a particular context?'.

Where the protein of food $A$ has given a lower value than the protein of food $B$, we may still reasonably consider using $A$ rather than $B$ provided that the total cost of the most economic and still satisfactory diet based on $A$ is less than that of any similarly satisfactory diet based on $B$. Since the combination of foods available is so great and their relative prices so variable, one has usually to attempt to predict the quality of a particular diet from its chemical composition.

\section{Groundnut flour as an example}

The difficulties are best seen with an actual example. Groundnut flour is about the least well-balanced of the common protein-rich foods in its amino acid composition and yet has been recommended for improving weanling children's diets

\footnotetext{
"On leave from the Department of Biochemistry, University of Natal,
} 
in India and parts of Africa. Since it is relatively cheap and abundant, will quantity make up for quality or will the adverse effects of imbalances nullify this?

In well-prepared groundnut flour methionine, lysine and threonine are almost equally limiting for the rat (McOsker, I962; Black \& Cuthbertson, I963); methionine is first limiting and lysine second limiting for the chick (Grau, I946; Milner $\&$ Carpenter, 1963 ). Severe processing can cause sufficient damage to the lysine for it to become the first limiting amino acid for both species (Bensabat, Frampton, Allen \& Hill, I958; McOsker, I962; Fisher, 1965; Anantharaman \& Carpenter, I 965), so that there is a problem of differences between samples.

FAO (1957) suggest an 'ideal' amino-acid mixture and compare it with that of a series of actual foods including groundnut flour. This follows Mitchell \& Block $\left(194^{6-7}\right)$ who first calculated the 'chemical score' of a protein food, as the lowest of the values obtained when the level of each essential amino acid ( $\mathrm{g} / \mathrm{I} 6 \mathrm{~g}$ nitrogen) in the test food was expressed as a percentage of the corresponding value for the protein of whole egg. Bender (196I) also has calculated 'scores' for groundnut flour in comparison with a 'target' mixture of essential amino acids corresponding to the requirements of young rats. All agree that sulphur amino acids limit the score of groundnut flour, though some workers ignore the fact that methionine is even more deficient in relation to requirements than is the combined supply of methionine and cystine (Table $\mathrm{I}$ ).

Table I. Values for methionine $(M)$ and cystine $(C)$ used by different authors for calculating the protein score of groundnut flour

\begin{tabular}{|c|c|c|c|c|c|c|c|}
\hline \multirow[b]{2}{*}{ Authors } & \multirow{2}{*}{$\begin{array}{l}\text { Basis for } \\
\text { standard }\end{array}$} & \multicolumn{2}{|c|}{$\begin{array}{l}\text { Standards for } \\
\text { 'ideal' protein } \\
(\mathrm{g} / \mathrm{I} 6 \mathrm{~g} \mathrm{~N})\end{array}$} & \multicolumn{2}{|c|}{$\begin{array}{c}\text { Analytical } \\
\text { value }(\mathrm{g} / \mathrm{I} 6 \mathrm{~g} \mathrm{~N})\end{array}$} & \multicolumn{2}{|c|}{$\begin{array}{c}\text { Calculated } \\
\text { score based on }\end{array}$} \\
\hline & & M & $\mathrm{M}+\mathrm{C}$ & $\mathbf{M}$ & $\mathrm{M}+\mathrm{C}$ & $\mathbf{M}$ & $\mathbf{M}+\mathbf{C}$ \\
\hline Mitchell \& Block (1946-7) & Whole egg & $4 \cdot 1$ & $6 \cdot 5$ & $\mathrm{I} \cdot 2$ & $2 \cdot 8$ & 24 & - \\
\hline FAO (1957) & Human needs & $2 \cdot 3$ & $4 \cdot 3$ & 0.9 & $2 \cdot 4$ & $(39) \dagger$ & 56 \\
\hline Bender (196I) & Rat's needs & - & $4 \cdot 7$ & - & $2 \cdot 0-2 \cdot 8$ & - & $43-59$ \\
\hline $\begin{array}{l}\text { (USA) National Research } \\
\text { Council ( } 1960) \\
\text { de Muelenaere } 8 \\
\text { Carpenter (unpublished) }\end{array}$ & Chick's needs & $2 \cdot 3$ & $4 \cdot 0$ & $\mathrm{I} \cdot \mathrm{Z}^{*}$ & -7 & 52 & 69 \\
\hline
\end{tabular}

*Or I. I g/ I6 g N methionine 'available' to Streptococcus zymogenes (Ford, I962).

$\uparrow$ The FAO report ignores this value and lists 56 .

\section{Pig and poultry rations}

High levels of groundnut meal have been tested as a substitute for animal protein in supplementing cereals for young pigs after weaning, i.e. to investigate a problem analogous to that of supplementing children's diets in the developing countries. Woodman \& Evans (195I) carried out both group-feeding and nitrogen balance studies and have reported their results in sufficient detail for further calculations to be made from them.

With diminishing response to extra protein it was difficult to pin-point one level of groundnut meal as exactly that required to equal the performance obtained with 
a good-quality animal protein supplement. Approximately equivalent performance was obtained when ro parts of groundnut protein were used as when $4 \frac{1}{2}$ parts of white-fish meal protein were used (the latter having previously been found to be optimal under the experimental conditions used). This quantity of groundnut flour is no more than that required to provide the pig's known requirements for methionine and lysine. In later comparisons, using generally similar diets but of higher energy content, the growth observed on a high-groundnut diet was inferior (Jones, Hepburn, Cadenhead \& Boyne, I962).

Results with practical diets with changing proportions of ingredients are difficult to interpret. We have carried out a simpler experiment (unpublished) using groundnut flour (plus lysine) as the sole protein source for chicks at levels providing 20-37\% protein in diets of the usual 'purified' type (cf. Milner \& Carpenter, 1963). Treatments including supplementary methionine were also tested. It will be seen from Table 2 that if $37 \%$ groundnut protein was used so as to provide $0.4 \%$ (or $\mathrm{I} \cdot 47 \mathrm{mg}$ / metabolizable kcal) of 'available methionine' in the diet, growth was not significantly different from either that on a lower-protein diet supplemented with methionine or that on a well-balanced control diet. Thus the severe deficiency of methionine in groundnut flour did not prevent its being used as an effective source of this amino acid.

Table 2. Response of chicks to diets containing groundnut flour as the sole protein source, with and without extra methionine

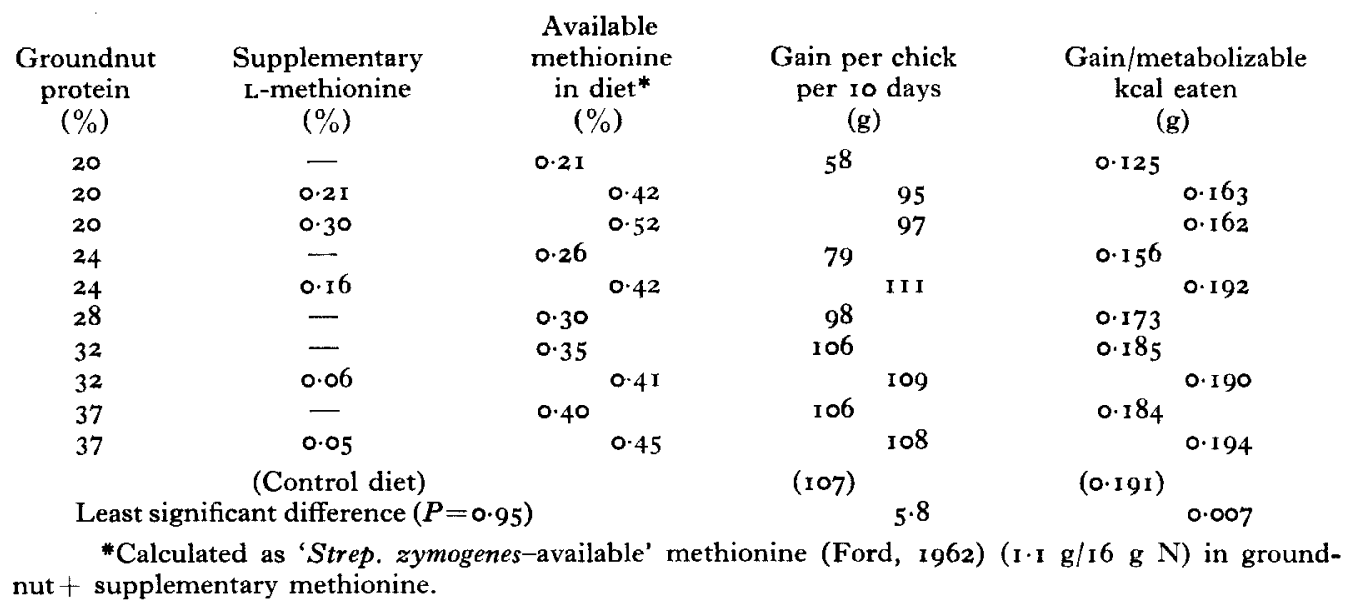

Grau \& Kamei (1950) who used soya as their protein source, concluded that raising the dietary protein from 20 to $40 \%$ increased the 'methionine+cystine' requirement of chicks from 0.8 to $\mathrm{I} . \mathrm{I} \%$ of the diet. This increased requirement is not so great that it entirely offsets the effect of adding a protein with even a relatively low methionine content. Similar results were obtained for lysine requirements at different protein levels (Grau, 1946).

Results from two reports of the effect of protein level on the lysine requirements of rats are illustrated in Fig. I. Bressani \& Mertz (1958) concluded that the require- 
ment did not differ significantly with diets containing maize gluten (first limiting in lysine) at protein levels from 12 to $40 \%$ of the diets. Munaver \& Harper ( 1959 ), who used wheat gluten, concluded (without statistical analysis) that lysine requirement was increased at the higher protein levels. The contradictory conclusions from similar results illustrate the difficulty of interpreting the small differences
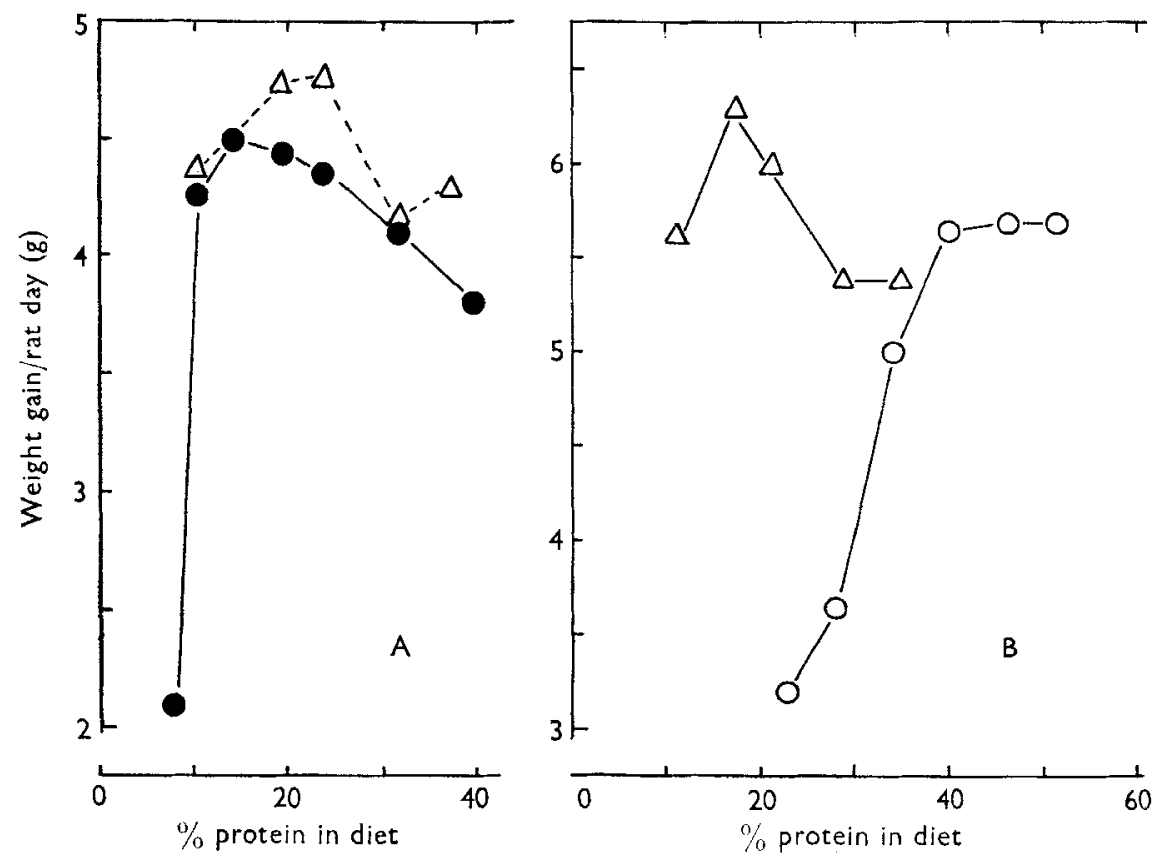

Fig. 1. Weight gains of rats as reported by (A) Bressani \& Mertz (1958) and (B) Munaver \& Harper (1959) on diets containing maize gluten and wheat gluten respectively as the sole protein sources. Supplements used: $\mathrm{O}-\mathrm{O}$, none; - $-\mathrm{L}$-lysine to give each diet a total content of $0.8 \%$ lysine; $\triangle \cdots \Delta$, L-lysine to give each diet a total content of $1.0 \%$ lysine.

observed with those near-to-optimal diets; the problem is whether or not to see trends where differences are not statistically significant. Neither group reported values for food consumption. Although Munaver \& Harper (1959) concluded that extra lysine was required with higher protein levels, they still obtained good growth with high levels of unsupplemented wheat gluten.

In this kind of study another problem is to know what proportion of the limiting amino acid in the basal diet is available to the animal. Munaver \& Harper (1959) had four diets of $20-40 \%$ protein content all containing $\mathrm{I} \cdot 0 \%$ lysine, with varying proportions from wheat gluten and the synthetic chemical. Since growth was least on the two diets of highest protein content, they concluded that the lysine requirement was increased. If the lysine in wheat gluten is taken to be $80 \%$ available (cf. Harper $\&$ de Muelenaere, I96I), the level of available lysine in the diets would have fallen from 0.9 to $0.8 \%$ as the protein level rose, which would explain a proportion of the apparent increased requirement at the high protein level. 
Miller-Payne predictions

It is implicit in some tables of 'nutritional requirements' that one can work out the adequacy of a diet from its calculated contents of individual amino acids, disregarding any unbalancing effect of excess total protein (e.g. Agricultural Research Council, I963). This is inconsistent with the theoretical model constructed by Miller \& Payne (1963) and applied successfully to predicting the growth of both pigs and poultry in some instances. Their assumption is that the maximum proportion of food nitrogen utilizable by an animal is $\mathrm{S}(\mathrm{I}-0.019 \mathrm{P})$, where $\mathrm{S}$ is the chemical score (as a fraction) of the protein mixture in the diet and $\mathrm{P}$ the proportion of the metabolizable energy in the diet derived from protein. The formula was arrived at from a study of the authors' own results with weanling rats, but they have suggested that it is applicable also to the young of man, dog and pig and to the chick. Live-weight gains have also been predicted (when protein limits growth) from food intake and body-weight data, by assuming that weight gain contains $17 \%$ protein and that the nitrogen used for maintenance is $250 \mathrm{mg} /$ day per body-weight $(\mathrm{kg})$ to the power 0.73 . Their formula may be expressed as:

$$
\text { Weight gain }(\mathrm{g} / \text { day })=\frac{\mathrm{I} 00}{\mathrm{I} 7}\left\{\mathrm{~g} \text { protein eaten } \times \mathrm{S}(\mathrm{I}-0.0 \mathrm{I9} \mathrm{P})-\mathrm{I} \cdot 5^{6} \mathrm{~W}^{\mathbf{0 . 7 3}}\right\} .
$$

Applying this formula to the results of the chick experiment already set out in Table 2 gives the results set out in Table 3. Taking published figures

Table 3. Found and predicted weight gains of chicks receiving groundnut $(+$ lysine $)$ as their sole protein source

\begin{tabular}{|c|c|c|}
\hline \multicolumn{3}{|c|}{ Dietary protein level } \\
\hline \multirow[t]{2}{*}{$\%$ by wt } & \multicolumn{2}{|c|}{$\%$ of calories } \\
\hline & $\mathrm{A}+$ & $\mathrm{B} \dagger$ \\
\hline I 4 & (15) & $(14.5)$ \\
\hline 20 & $(23)$ & $(21)$ \\
\hline 24 & (29) & (25) \\
\hline 28 & (35) & (29) \\
\hline 32 & (4I) & $(33.5)$ \\
\hline 37 & $(5 \mathrm{I})$ & $(38 \cdot 5)$ \\
\hline
\end{tabular}

\begin{tabular}{|c|c|c|}
\hline \multicolumn{3}{|c|}{ Weight gain (g/day) } \\
\hline \multirow[t]{2}{*}{ Found } & \multicolumn{2}{|c|}{ Predicted for chemical scores of $52-69^{*}$} \\
\hline & A† & $\mathrm{B} \dagger$ \\
\hline 1.67 & $\mathrm{I} \cdot 0-\mathrm{I} \cdot 8$ & $I \cdot 2-2 \cdot I$ \\
\hline 5.8 & $3 \cdot 0-4 \cdot 4$ & $3 \cdot 6-5 \cdot 3$ \\
\hline $7 \cdot 9$ & $3 \cdot 2-4 \cdot 8$ & $4 \cdot 5-6 \cdot 5$ \\
\hline $9 \cdot 8$ & $3 \cdot 2-4 \cdot 8$ & $5 \cdot 2-7 \cdot 6$ \\
\hline 10.6 & $2 \cdot 1-3 \cdot 3$ & $5 \cdot 1-7 \cdot 5$ \\
\hline $10 \cdot 6$ & Nil & $4.7-6.8$ \\
\hline
\end{tabular}

*Calculated from the Miller-Payne equation (Miller \& Payne, r963).

†Calculated from two estimates for the metabolizable energy content of each diet: (A) from published figures for each ingredient, with values declining from 3.45 to $2.72 \mathrm{kcal} / \mathrm{g}$ with increasing groundnut levels; (B) from the Miller \& Payne (I 9.59) formula which gives an almost constant value of 3.84 $\mathrm{kcal} / \mathrm{g}$.

†Old data (Milner \& Carpenter, r 963 ).

for the metabolizable energy of feeding-stuffs including one for groundnut meal of $2.68 \mathrm{kcal} / \mathrm{g}$ (Zablan, Griffith, Nesheim, Young \& Scott, 1963), we obtained the $\mathrm{P}$ values shown in column $\mathrm{A}$ of Table 3 . However, the formula ' $0.95 \times$ gross energy $(\mathrm{kcal} / \mathrm{g})-0.075 \times \mathrm{N}(\%)$ ', originally suggested by Miller \& Payne (1959) and used for all their subsequent predictions, gives the lower values shown in column $\mathrm{B}$. These differences have a considerable effect on the predicted growth rates. Thus, for the diet of highest protein level one would expect the chicks to lose weight on the 
first assumption, and gain $5.7 \mathrm{~g}$ /day on the second: in fact they gained over $10 \mathrm{~g} /$ day. The prediction from the trial with $14 \%$ protein (Milner \& Carpenter, 1963 ) was much closer. The published results (Summers \& Fisher, 196r) used by Miller \& Payne (1963) to demonstrate the application of the formula were also for diets of approximately $14 \%$ protein content.

The controversial part of the theory is the reduction of the effective value of the dietary protein through multiplication by the factor I-0.019 P. From this it would follow that only a decline in NDpCal \% (protein kcal retaired/roo kcal eaten) can be predicted by increasing the level of protein calories above $26 \%$ in a diet, yet the chick results under discussion have not shown this. Records with broiler chicks have also shown NDpCal \% of up to 18 (Carew, Hopkins \& Nesheim, 1964) although the model indicates a theoretical maximum of 14.7 .

The only chick data of net protein utilization (NPU) determined at different levels, up to $25 \%$ protein, are for soya protein (Summers \& Fisher, r96r). Here the NPU values fall linearly with protein at the rate consistent with the Miller-Payne regression lines.

\section{Findings with rats}

Since chicks can grow more quickly than rats, it seems only reasonable that they might be able to make more efficient use of high levels of unbalanced protein. For the original calculation of a regression of NPU against protein level, results obtained with one material, wheat gluten, of low chemical score were used (Miller \& Payne, 196I), but shown only in a scatter diagram. Calculation of NDpCal \% at different

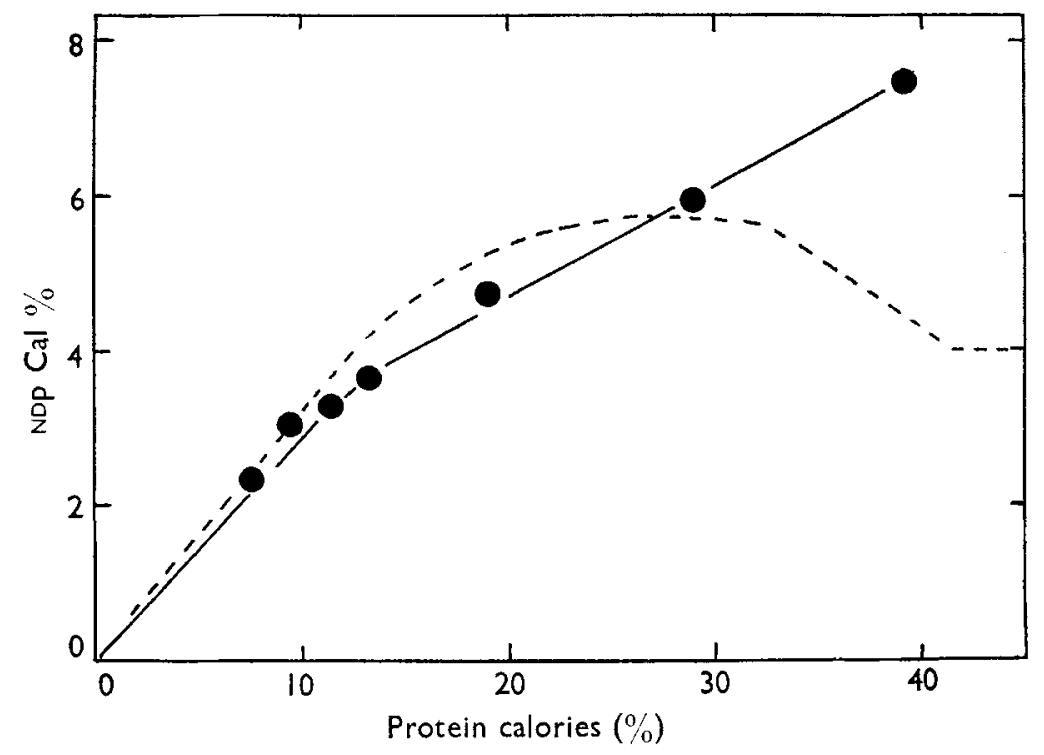

Fig. 2. The retention of nitrogen (expressed as protein calories per 100 calories eaten) by rats receiving wheat gluten as their sole source of protein (data recalculated from Barnes, Bates \& Maack, 1946). - actual rat values; - , lines of linear regression above and below maintenance, fitted by eye; - - , predicted curve from the Miller \& Payne (I96I) equations for a protein with a NPU (st.) of 32. 
protein levels from another experiment (Barnes, Bates \& Maack, I946) showed that the value at the highest level was greater than expected from the original equations (Fig. 2), but so was Miller \& Payne's own value of 7.8 (read from graph) at a $\mathrm{P}$ of 37 , as also that of 8.0 (read from graph) at a $\mathrm{P}$ of $4^{\circ}$ (Morrison, Sabry, Gridgeman \& Campbell, 1963$)$.

Njaa (1962), Morrison et al. (1963) and Hegsted (1964) have all reported that recalculation of their own rat data or that of others has given values that do not always fit the Miller-Payne predictions. It appears therefore that the hypotheses of Miller \& Payne ( 1963 ) have stimulated thought and investigation, but that the extent to which they are applicable is a matter of debate.

\section{Conclusions}

Under certain conditions, higher levels of poor protein will result in nearly as good growth as can be obtained with practical diets containing good-quality protein. This good growth is obtained notwithstanding an increased requirement for the limiting amino acid with increased protein levels.

The possibility of predicting the performance to be obtained with a particular protein depends firstly on the accuracy of the chemical score assigned to it. This depends on three criteria: the requirement for the essential amino acids of the species under consideration, the amino acid composition of the protein and the biological availability of those amino acids. Knowledge of amino acid requirements of different species is still incomplete. Despite the advent of automatic analysers, considerable variation still exists between amino acid analyses of the same material, particularly for the sulphur-containing amino acids. Availability of amino acids is not yet taken into consideration, because of insufficient data.

Although amino acid requirements can increase with higher total protein levels, the Miller-Payne equation for predicting this effect may need modification for highprotein diets.

One of us (H. J. H. de M.) is indebted to the Wellcome Foundation for a grant to work at the University of Cambridge.

\section{REFERENCES}

Agricultural Research Council (1963). The Nutrient Requirements of Farm Livestock: No. I : Poultry. London: Agricultural Research Council.

Allison, J. B. (1955). Physiol. Rev. 35, 664.

Anantharaman, K. \& Carpenter, K. J. (1965). Proc. Nutr. Soc. 24, xxxii.

Barnes, R. H., Bates, M. J. \& Maack, J. E. (1946). F. Nutr. 32, 535.

Bender, A. E. (196r). Publ. nat. Res. Coun., Wash., no. 843, p. 407.

Bensabat, L., Frampton, V. L., Allen, L. E. \& Hill, R. A. (1958). F. agric. Fd Chem. 6, 778.

Black, A. E. \& Cuthbertson, W. F. J. (Ig63). Proc. Nutr. Soc. 22, xxi.

Bressani, R. \& Mertz, E. T. (1958). F. Nutr. 65, 481 .

Carew, L. B., Hopkins, D. T. \& Nesheim, M. C. (1964). F. Nutr. 83, 300.

Carpenter, K. J. (195I). Brit. F. Nutr. 5, 243.

FAO (1957). F.A.O. nutr. Stud. no. 16.

Fisher, H. (1965). Y. Sci. Fd Agric. 16, 390.

Ford, J. E. (1962). Brit. F. Nutr. 16, 409.

Grau, C. R. (1946). F. Nutr. 32, 303. 
Grau, C. R. \& Kamei, M. (1950). F. Nutr. 41, 89.

Harper, A. E. \& de Muelenaere, H. J. H. (196r). Proc. int. Congr. Biochem. v. Moscow, 8, 82.

Hegsted, D. M. (1964). In Mammalian Protein Metabolism. Vol. 2, Chapter 14. [H. N. Munro and J. B. Allison, editors.] New York \& London: Academic Press Inc.

Jones, A. S., Hepburn, W. R., Cadenhead, A. \& Boyne, A. W. (1962). Anim. Prod. 4, 185.

McOsker, D. R. (I 962). J. Nutr. 76, 453.

Miller, D. S. \& Payne, P. R. (1959). Brit. F. Nutr. 13, 501.

Miller, D. S. \& Payne, P. R. (196r). Brit. F. Nutr. 15, I I.

Miller, D. S. \& Payne, P. R. (1963). F. theor. Biol. 5, 1398.

Milner, C. K. \& Carpenter, K. J. (1963). Proc. Nutr. Soc, 22, xxii.

Mitchell, H. H. \& Block, R. J. (1946-7). Nutr. Abstr. Rev. 16, 249.

Morrison, A. B., Sabry, Z. I., Gridgeman, N. T. \& Campbell, J. A. (1963). Canad.7. Biochem. Physiol. 4I, 275.

Munaver, S. M. \& Harper, A. E. (1959). I. Nutr. 69, 58.

National Research Council (1960). Publ. nat. Res. Coun., Wash., no. 827.

Njaa, L. R. (1962). Brit. F. Nutr. 16, 185.

Summers, J. D. \& Fisher, H. (1961). F. Nutr. 75, 435.

Woodman, H. E. \& Evans, R. E. (1951). F. agric. Sci. 41, 102.

Zablan, T. A., Griffith, M., Nesheim, M. C., Young, R. J. \& Scott, M. L. (I963). Poult. Sci. $42,619$.

\section{Effects of amino acid excess on metabolism}

\section{By H. N. Munro, Institute of Biochemistry, University of Glasgow}

Adverse nutritional effects have been reported when the diet of an animal, usually a growing animal, is supplemented with a single amino acid, a mixture of amino acids, or a protein of poor nutritional quality. In order to facilitate investigation of these adverse effects, Harper ( 1964 ) has suggested that all the recorded observations can be classified into one of three groups, namely amino acid antagonisms, amino acid imbalances and amino acid toxicities, on the grounds that these groups probably represent different metabolic mechanisms. The justification for separate classification is most obvious with amino acid antagonisms, in which structurally related amino acids compete with one another in metabolic reactions and thus depress amino acid utilization. There may also be a single type of metabolic mechanism underlying amino acid imbalances, in which a change in the proportion of the dietary amino acids results in a depression of growth rate that can be prevented by adding a supplement of the most limiting essential amino acid in the diet. Toxicities due to excessive intakes of single amino acids are classified as a separate group by Harper (1964) and are regarded as having no common underlying mechanism. For example, an excessive intake of tyrosine produces changes in the corneal epithelium and conjunctiva, accompanied by swelling of the feet (Schweizer, 1947). Excessive intakes of other amino acids generally cause loss of weight without inducing signs as specific as those caused by tyrosine. Furthermore, the amounts of individual amino acids needed to cause toxic effects vary greatly, and Harper (1964) has pointed out that those of greatest toxicity (methionine, tyrosine, tryptophan and histidine) are involved in many metabolic pathways. These various observations suggest that within the group of amino acid toxicities there may be several different types of metabolic change due to overloading the system with a single amino acid. 